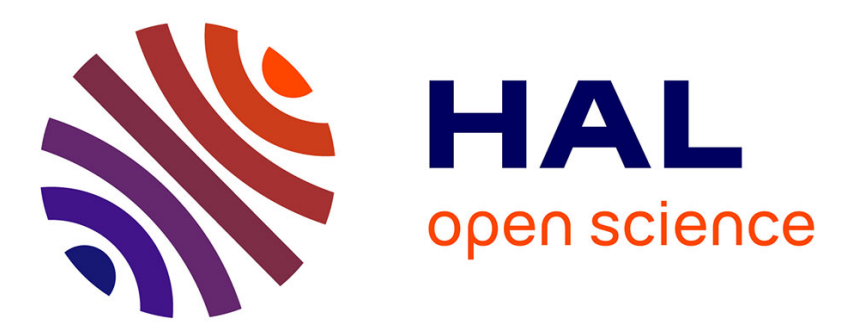

\title{
HORNBOSTEL AND ME. EXPECTATIONS TOWARDS HISTORICAL RECORDINGS OF THE EWONDO DRUM LANGUAGE (SOUTH CAMEROON)
}

\author{
Susanne Fürniss
}

\section{To cite this version:}

Susanne Fürniss. HORNBOSTEL AND ME. EXPECTATIONS TOWARDS HISTORICAL RECORDINGS OF THE EWONDO DRUM LANGUAGE (SOUTH CAMEROON). International Forum on Audio-Visual Research, 2015, 6, pp.74 - 100. halshs-02429756

\section{HAL Id: halshs-02429756 \\ https://shs.hal.science/halshs-02429756}

Submitted on 6 Jan 2020

HAL is a multi-disciplinary open access archive for the deposit and dissemination of scientific research documents, whether they are published or not. The documents may come from teaching and research institutions in France or abroad, or from public or private research centers.
L'archive ouverte pluridisciplinaire HAL, est destinée au dépôt et à la diffusion de documents scientifiques de niveau recherche, publiés ou non, émanant des établissements d'enseignement et de recherche français ou étrangers, des laboratoires publics ou privés. 


\title{
HORNBOSTEL AND ME. \\ EXPECTATIONS TOWARDS HISTORICAL RECORDINGS OF THE EWONDO DRUM LANGUAGE (SOUTH CAMEROON)
}

Susanne Fürniss, Directrice de Recherche au CNRS, Paris, furniss@mnhn.fr

\begin{abstract}
Historical recordings are not only a source for the study of cultural change, but also for ethnomusicological epistemology. At least, this is one of the multiple expectations that a contemporary scholar may have towards the first available sound recordings. The waxcylinder collection of the Berlin Phonogramm-Archiv contains some experimental recordings which document the use of speech surrogates among the Ewondo in Cameroun (Jaunde in colonial German). These recordings have been made in 1909 in Berlin by Erich Moritz von Hornbostel at a moment when the linguist Hermann Nekes established the tonology of ewondo in 1911. The way this collection is constructed suggests a close collaboration between both scholars.

The present article searches for the connection between the musicologist and the linguist. It puts into parallel informations on the drummed messages, the Cameroonian collaborators and the recording sites given independantly by each scholar. Thus, it is not only about the cultural knowledge transmitted by the historical recordings, but also about methodology for the study of drum languages and epistemological issues concerning interdisciplinary research. The latter are seen both in the general scientific and colonial context at the beginning of the $20^{\text {th }}$ century and from the perspective of the $21^{\text {st }}$ century. Finally, this is a case-study on interconnecting different archival and published sources.
\end{abstract}

\section{Zusammenfassung}

Historische Aufnahmen sind nicht nur eine Informationsquelle für das Studium kulturellen Wandels, sondern auch für musikethnologische Epistemologie. Zumindest ist dies eine der Erwartungen, die ein zeitgenössischer Wissenschaftler an die ersten verfügbaren Tonaufnahmen stellen kann. Die Wachswalzensammlung des Berliner Phonogramm-Archivs enthält einige experimentelle Aufnahmen, die die Verwendung von Sprachsurrogaten unter den Ewondo in Kamerun (Jaunde im kolonialen Deutsch) dokumentieren. Diese Aufnahmen wurden im Jahr 1909 in Berlin von Erich Moritz von Hornbostel gemacht, zeitgleich mit der Beschreibung des Tonologie des ewondo durch den Sprachwissenschaftler Hermann Nekes (1911). Die Gliederung dieses Aufnahmen deutet auf eine enge Zusammenarbeit zwischen den beiden Gelehrten hin.

Der vorliegende Artikel sucht nach der Verbindung zwischen dem Musikwissenschaftler und dem Linguisten. Er stellt Parallelen her zwischen den unabhängig von beiden Wissenschaftlern gegebenen Informationen $\mathrm{zu}$ den [75] getrommelten Nachrichten, den Kameruner Mitarbeitern und den Aufnahmeorten. Somit geht es hier nicht nur um durch die historischen Aufnahmen übermitteltes kulturelles Wissen, sondern auch um die Methodik zur Untersuchung der Trommelsprachen und um epistemologische Fragen der interdisziplinären Forschung. Diese werden sowohl im allgemeinen wissenschaftlichen und kolonialen Kontext zu Beginn des 20. Jahrhunderts und aus der Sicht des 21. Jahrhunderts behandelt. Schließlich ist dies ein Fallstudie über die Verknüpfung von Archivmaterial und veröffentlichten Quellen.

Historical recordings are not only a source for the study of cultural change, but also for ethnomusicological epistemology. At least, this is one of the multiple expectations that a contemporary scholar may have towards the first available sound recordings. This was the case when I discovered the wax-cylinder recordings of Ewondo speech surrogates in the Berlin Phonogramm-Archiv. This collection contains some experimental recordings which 
document the use of speech surrogates among the Ewondo in Cameroun (Jaunde in colonial German). These recordings have been made in 1909 in Berlin by Erich Moritz von Hornbostel at a moment when the linguist Hermann Nekes established the tonology of ewondo in 1911. The way this collection is constructed suggests a close collaboration between both scholars. In this, I perceived strong parallels to the interdisciplinary practice I experience currently as a 21 st century scholar. Motivated by this convergence with my own research, the present article searches for the connection between the musicologist and the linguist. Thus, the present article is not only about the cultural knowledge transmitted by the historical recordings, but also about methodology for the study of drum languages and epistemological issues concerning interdisciplinary research. The latter are seen both in the general scientific and colonial context at the beginning of the $20^{\text {th }}$ century and from the perspective of the $21^{\text {st }}$ century. Finally, this is a case-study on interconnecting different archival and published sources.

[76]

\section{Recordings from South Cameroon in the Phonogramm-Archiv}

South Cameroon - the region I conduct fieldwork in since 1999 - is represented in the Berlin Phonogramm-Archiv by five collections containing 186 cylinders, recorded between 1907 and 1909 (Ziegler 2006).

Thanks to Erich Moritz von Hornbostel's and Felix von Luschan's efforts to supply a phonograph to any person willing to do recordings in the remote areas they were travelling to (Abraham \& Hornbostel 1904, Luschan 1908), three collections have been recorded in their cultural context in the former German protectorate of Kamerun which included the actual South Cameroon, Equatorial Guinea, and North Gabon:

Tessmann Spanisch-Guinea, 1907-1908' Günther Tessmann, the head of the Lübecker Pangwe-Expedition, recorded 86 cylinders that are complementary to his important monography Die Pangwe (Tessmann 1913). They contain music and oral literature of the Fang as well as some Ewondo-songs.

Waldow Kamerun, 1907. The colonial doctor Hans Waldow recorded 29 cylinders with songs of the Bagyeli ${ }^{2}$, Banen, Bulu, Ewondo and Ngumba in Fudde, Lolodorf and Ndondo.

Zenker Kamerun, 1908. Georg Zenker, botanist and important member of the colonial administration $^{3}$, recorded 8 cylinders with dance songs of the Bakoko, Bulu and Mabi in Kribi.

\footnotetext{
${ }^{1}$ The documentation indicates 1907 as the year of Tessmann's recordings. However, a close comparison of the locations where the recordings have been made with the description of Tessmann's journey (Tessmann 1913), has brought to evidence that at least the thirteen cylinders with xylophone music have been recorded in 1908 (Lacombe 2013).

2 Toponyms and ethnonyms are actualized as far as possible.

${ }^{3}$ One of his achievements was the foundation of the actual capital Yaoundé (Zenker 1895, Laburthe-Tolra 1970).
} 
Two other collections have been recorded by Hornbostel in Berlin in 1909 with young Cameroonians who spent some time in the German capital:

Archiv Kamerun contains 41 cylinders with songs from the Bakoko, Banoho, Bulu, Duala, Mabea and Malimba, sung by two young men from the Southern Cameroonian Atlantic coast.

Archiv Jaunde contains 14 cylinders with songs, instrumental music and speech surrogates of the Ewondo ("Jaunde" in colonial German).

\subsection{Speech surrogates in Archiv Jaunde}

Four cylinders of this collection document speech surrogates produced [77] on two different instruments: cylinders $n^{\circ} 2,3$ and 5 concern messages played on a slitdrum, $n^{\circ} 13$ is played on a double-bell. Three of them are analytical recordings and explicitely illustrate the link between a drummed and a spoken message. A fifth drum language recording is mentioned in the documentation $\left(n^{\circ} 14\right)$, but the mention is crossed out and replaced by comments on the xylophone recorded on cylinders $n^{\circ} 8$ to 12 . The recording confirms this information: cylinder $n^{\circ} 14$ presents the scale of a xylophone.

The documentation of these four recordings is heterogeneous and very poor (see the documentation sheet in the appendix). The note for $n^{\circ} 5$ mentions only "Lament on the speechdrum", but contains no indication of what is supposed to be said, neither in German, nor in Ewondo. For the other recordings, there is at least a German translation of the drummed phrase, for $\mathrm{n}^{\circ} 3$ also a linguistic transcription of the Ewondo phrase. Unfortunately, contrary to other recordings by Hornbostel, this is the entire available information. The lack of documentation is a problem already addressed by Susanne Ziegler in her article on Hornbostel's role in the activities of the Archive. According to the author, it is possible that the actual documentation might not be complete (Ziegler 1998:147).

\section{Hornbostel's publications on African Music}

Another point already mentioned by Ziegler (1998:154) is that in many cases there is no written scientific exploitation of the recordings by Hornbostel himself. This seems to be the case not only with the collection considered here, but also with the collection Archiv Kamerun. In his survey of Hornbostel's studies of African Music (Hornbostel 1909, 1917, 1928, 1933), Gerd Grupe mentions six populations from Tanzania, Ruanda and Cameroon, but not the Ewondo and none of the other African cultures documented by recordings made in the Archive either by Hornbostel himself or by another person ${ }^{4}$ (Grupe 1998:107). In his

\footnotetext{
${ }^{4}$ Archive recordings identified as having been made by Hornbostel (Ziegler 2006): Archiv Duala (1905, 1 cylinder with spoken language), Archiv Kongo (1908-09, 41 cylinders with songs and drum rhythms), Archiv Ostafrika (1911, 3 cylinders with songs), Archiv Suaheli I and II (1902 and 1910, 6 cylinders with songs), Archiv Sudan (1909, 15 cylinders with vocal and instrumental music).

Other Archive recordings of African music: Archiv Ewe I (1904, 18 cylinders with vocal and instrumental music, some of which having been recorded by Carl Meinhof), Archiv Ful (2 cylinders with spoken language), Archiv Gweabo (1930, 4 cylinders with songs and language recorded by George Herzog), Archiv Senegambien (1910, 37 cylinders with vocal and instrumental music recorded by Erich Fischer), Archiv Somali (1910, 24
} 
synthetic article on drum [78] language, Hornbostel (1920) hardly mentions the Cameroonian speech surrogates (Ewondo and Duala), but stays quite general in his descriptions. As Hornbostel considered that the analyzing person must not necessarily be the person who recorded the music (Hornbostel 1928:33), he himself wrote on music he had never studied in its cultural context, but only on the basis of the recordings and informations supplied by other collectors; a case in point would be Hornbostel (1913) writing the chapter "Musik" in Tessmann's Die Pangwe.

\subsection{The context of Hornbostel's interest in speech surrogates}

\section{Early 20th-century studies on speech surrogates}

Since the Berlin-Conference in 1885-86, the discovery of other cultures and societies and their submission under the German colonial system went along with the study of customs and languages of the people living in the protectorate of Cameroon. The phenomenon of drum languages immediately fascinated not only scholars, but also persons of various horizons. Missionaries, teachers and soldiers were remarkable observers and published seven articles on this subject between 1894 and 1920.

Carl Meinhof (1894), Professor for African languages at the Seminary for Oriental Languages in Berlin, was one of the first authors to mention the existence of this communication system in a very short text. R. Betz (1898), a German teacher in Duala, published the first detailed study of the Duala drum language with about 80 pages of musical transcriptions of 275 messages $^{5}$. The missionaries of the Pallotine-mission Hermann Skolaster (1910) and Hermann Nekes (1912) dedicated publications to drummed and "called" messages. Gunther Tronje von Hagen (1914), an officer of the colonial protection army, wrote a chapter on Bulu drum language in his remarkable Manual of the Bulu language which includes a chapter on music with precious musical transcriptions by Hermann Harttmann, also officer in the German army. In 1916 appeared the first genuine multidisciplinary approach of the phenomenon by Georg Thilenius (ethnologist), Carl Meinhof (linguist) and Wilhelm Heinitz (phonetician). Finally, the linguist Martin Heepe (1919/20) completed Nekes' study on the Ewondo drum language on the basis of sound recordings made specifically for his research ${ }^{6}$.

[79]

\section{Early 20th-century studies on tone languages}

The most important linguistic studies on African tone languages are produced at the same time as the studies of drum languages. For Cameroon, these are the very first serious

\footnotetext{
cylinders with vocal and instrumental music), Archiv Suaheli III (1937, 3 cylinders of songs recorded by Marius Schneider), Archiv Südafrika (1900, 3 cylinders of songs recorded by Otto Abraham).

${ }^{5}$ See the recent study of Moritz Nagel (2014) on Duala drum language.

${ }^{6}$ Six discs were recorded in Hamburg in 1913, at the Seminary for African and Oceanian Languages with 95

"drum signals" played by the Ewondo-chief Karl Atangana (Heepe 1919/20:44).
} 
linguistic studies: Nekes (1911a, b, 1928), Schmidt (1912), Heepe ([ed.] 1919, [ed.] 1919/20), Heepe with Nekes (1926). Nekes was the first scholar to establish the tonology of the Ewondo ${ }^{7}$.

The discovery of tone languages was closely conditioned by the new recording techniques which emerged at the turn of the century. The linguists of African languages have immediately seized the interest of phonograms and of sound analyzing devices, especially for the study of tone and speech intonation. Heepe (1919) publishes an experimental phonetical study on this subject as introduction to his Jaunde-Texte ${ }^{8}$.

\subsection{Hornbostel's predisposition for experimentation and interdisciplinarity}

Hornbostel's recordings of Ewondo drum language represent an experimentation through analytical recordings and testify for the author's familiarity with experimental research protocols on one hand and for interdisciplinarity on the other. It is usefull to recall Hornbostel's biography and the general scientific framework in which the first studies of comparative musicology have been conducted in Berlin.

Erich Moritz von Hornbostel (Vienna 1877 - Cambridge 1935) has studied natural sciences and philosophy and made his $\mathrm{PhD}$ in chemistry. Together with Carl Stumpf and Otto Abraham, he founded comparative musicology at the Institute for Psychology. The aim was to transfer concepts and methods from acoustics, experimental psychology and physiology to the study of extra-European music. From 1905-1933, he was the Director of the PhonogrammArchiv and carried out many experiments in the domain of music psychology with musicians from different cultural backgrounds (Ziegler 1998:154).

Thus, interdisciplinarity was the core of his approach and his preoccupations.

[80]

\section{Hermann Nekes and the Ewondo-language}

Hornbostel's supposed research partner for the Ewondo drum language recordings is Hermann Nekes (Essen 1875 - Kew-Melbourne 1948) ${ }^{9}$. Priest for the Pallotine Mission, he stayed in Cameroon from 1901 to 1909 where he co-founded the missionary school in Mvolyé in 1903. Parallel to his religious activities, he conducted linguistic research and was in close contact with Meinhof (Laburthe-Tolra 1999:185). Nekes' aim was to translate the catechism and the Gospel together with three young Ewondo men, Martin Tabi, Joseph Ayisi and Pius Otou. He "worked for a translation that should be as exact and as elegant as possible with these young intelligent men who knew the numerous stylistic subtleties of the language" (ibid.).

\footnotetext{
${ }^{7}$ Ewondo is a Bantu language of the A72a branch of the revised Guthrie classification (Maho 2009).

8 This study was also based on recordings made with Karl Atangana. Heepe's recordings of Atangana have not been located at the beginning of the 21 st century; they seem to be lost.

${ }^{9}$ A more detailed biography and a publication list is published in Worms (1953). Nekes has later worked on Australian languages. In 1935, he initiated phonograph recordings in Australia (see correspondance with
} 
During his stay in Cameroon, Nekes had seized the importance of speech surrogates for the cognitive development of the young boys. Officer Harttmann observed that the capacity of drumming messages became the condition for the acceptation in the German missionary school:

"Father Nekes from the catholic mission in Jaunde required from each Jaunde-boy who wanted to be accepted at the missionary-school that he first was able to drum, otherwise he did not accept them" (Harttmann 1933:16).

Through the agency of the Pallotine mission, Nekes was invited to Berlin to lecture Ewondo at the Seminar from 1909 to 1916. Manuscripts of the Geheimes Staatsarchiv in Berlin, written between july 1908 and november 1909 and concerning the hiring of an Ewondo language teacher, testify for exchanges between the Director of the Seminar Eduard Sachau and the colonial army, the Pallotine mission and the Ministries for Education and for Foreign Affairs ${ }^{10}$. The appointment of "Father Nekes" from october 15th on has officially been signed by the Minister for Foreign Affairs on november 8, 1909. Several requests for the renewal of his contract were regularly accorded until at least july $1915^{11}$.

During this period, he finished his Manual of the Jaunde-language (Nekes 1911a) and two articles on tonology (Nekes 1911b) and speech surrogates [81] (Nekes 1912). The latter is an outstanding scientific work, both concerning its cultural contents and theoretical issues on drum languages.

\subsection{Speech surrogates among the Ewondo}

The reproduction of speech tones on slit-drums or other musical instruments is an ancestral and still common means of communication in West and Central Africa ${ }^{12}$. There are several situations in which people may employ speech surrogates. In every situation exists a stock of possible sentences. The drum reproduces only the melodic contour of the language by reducing the sentence to the succession of the linguistically relevant speech tones. Several devices exist to make sure that the message will be understood (Arom \& Cloarec-Heiss 1976).

In his manual, Nekes gives a linguistic example for the Ewondo's use of the slit-drum to announce funerals (1911a:112) and some of his texts contain drummed passages indicated by drum-syllables. Nearly hundred years later, drummed names and genealogies are still a central element of the funeral ceremonies of the Ewondo and the larger Beti-group they belong to (Abega 1987, Essele 2008). Several testimonies give evidence for the use of drum language

Marius Schneider, Berlin Phonogramm-Archive) together with his fellow Ernst Worms. 12 cylinders have been preserved (Ziegler 2006:318).

${ }^{10}$ GStA PK, I. HA Rep. 76 Kultusministerium, Va Sekt.2 Tit. X Nr 124 Adh V Bd. 6, leaflets 13 (march 2, 1909); 17 ( july 31st, 1908); 19 (february 25, 1909), 68 (july 1st, 1909); 107-8 (october 21st, 1909); 109 (october 18, 1909); 110 (november 8, 1909); 115 (september 23, 1909).

${ }^{11}$ GStA PK, I. HA Rep. 76 Kultusministerium, Va Sekt.2 Tit. X Nr 124 Adh V Bd. 6, leaflets 194-5 (april 30, 1910); 293 (august 17, 1910); 294 (august 10, 1910); Bd. 7, leaflets 36 (october 22, 1910); 138 (may 5, 1911); 139 (june 6, 1911); 181-2 (december 4, 1911); 185 (february 17, 1912); 233 (may 5, 1912); 234 (may 31, 1912).

${ }^{12}$ See among others: Eboué 1935, Nketia 1963, Ames, Gregersen \& Neugebauer 1971, Arom \& Cloarec-Heiss 1976, Sebeok \& Umiker-Sebeok 1976, Cloarec-Heiss 1997, Zemp 2004, Ne Nkamu 2011, Bourget 2013. 
by the colonial administration to transmit messages to the population (Harttmann 1933, Nekes 1912:78-9). Until today - in spite of cellphones -, slit-drum communication is frequently used by the Beti-Eton ${ }^{13}$.

Traditionally, each person has a specific name which is usually not pronounced orally, but which is expressed by the means of the slit-drum. This name is called ndán in Ewondo, translated by Nekes with "drum name" (1911a:274). While in early times of colonialisation, this name was a current identification of a person, few people know their drum name nowadays. Still, it exists and is drummed at the occasion of a person's funeral.

A specificity of the Beti is that the drum language may be transposed back onto the voice by a specific way of calling. This is conceptualized by the term of ekígá: "If the person who has to be called is far away, one uses the drum name either by the ekígá-call or by using the speech-drum" (op. cit.:107). Ekigá is called with the "drum syllables" $k u$ or $k \varepsilon$ (Nekes 1912:80). In the past, the double-bell nkén was also used as a substitute of the slit-drum when going from one place to another (op. cit.:75).

[82]

These general informations are necessary to understand both Hornbostel's recording method and some of his notes.

\section{What did I expect Hornbostel's recordings to tell me?}

Hornbostel's recordings are the starting-point for the research I am actually conducting on early 20th century recordings of drum language in German archives. The linguistic transcriptions of the Ewondo language in the documentation of Archiv Jaunde aroused my particular interest, as they are a clue for a more or less close contact between Hornbostel and linguists who worked on African tone languages at the beginning of the 20th century. I myself was raised in an interdisciplinary surrounding in very close contact with linguists. I collaborated with Gladys Guarisma on the relationship between speech tones and melodies (Fürniss \& Guarisma 2005) and compared notes with Jean-Marie Essono (2000) on Ewondo ${ }^{14}$. Thus, this type of collaboration seemed evident to me. In the light of Hornbostel's itinerary, I naturally supposed that Hornbostel and Nekes have worked together in a similar way as ethnomusicologist Simha Arom and linguist France Cloarec-Heiss (1976) have collaborated on Banda-Linda drum language throughout the entire research proces: from the construction of the object and the collection of experimental data to their analysis and the interpretation of the results.

Another presupposition has its origin in my ethnomusicological experience, i.e. the evidence that recordings are made in a specific perspective. Therefore, I supposed that these

\footnotetext{
${ }^{13}$ I carried out fieldwork among the Eton together with Kisito Essele in 2009 and 2012.

14 Together with Philippe Laburthe-Tolra, Essono has published the French translation of Heepe's JaundeTexte (1919) and commented the early 20th century Ewondo as it appears through Atangana's accounts (Laburthe-Tolra \& Essono 2005).
} 
four analytical recordings have been part of a collaborative research corpus on the link between language and music.

The lack of explicite documentation in the Phonogramm-Archiv, however, called for a meticulous search for any clue that might shed light on the framework in which Hornbostel's recordings have been made. Thus, the object of the present text is less the Ewondo drum language itself than the paradigm put up by Hornbostel and his connection with Nekes. It will moreover supply an illustration of the difficulty of putting together isolated pieces of a large puzzle in order to evaluate these historic testimonies which come to us in a very reduced form and the status of which is sometimes not very clear nowadays.

$[83]$

\section{Searching the Hornbostel-Nekes connection}

There are several hints for a more or less close contact between Hornbostel and Nekes.

\subsection{Hornbostel's recording protocol}

Hornbostel's quite specific recording protocol indicates that he knew about the different means of communication among the Ewondo. He takes advantage of the Ewondo's habit of calling a message and records not only the drummed and spoken version, but also a called realisation, as well as the mere whistled melodic contour of the utterance. In his written notes, he uses the same word as Nekes, Fernruf, literally "far-call".

The transcription of Archiv Jaunde $\mathrm{n}^{\circ} 2$ may serve as an example ${ }^{15}$. The recording starts with the obligatory pitch reference and the announcement of the contents (Luschan 1908:61). Hornbostel says: "Jaunde number two. Drum language: drummed, called and spoken".

Musical example 1: Archiv Jaunde 2 (Transcription S. Fürniss).

\footnotetext{
${ }^{15}$ Archiv Jaunde 2 has been part of Hornbostel's demonstration collection at the beginning of the 1920ies (Ziegler 2006:87).
} 
Except for the whistling, the same analytical protocol is followed for cylinders $\mathrm{n}^{\circ} 3$ and 13. Due to slight differences between the phonological realisation by the slit-drum and the phonetic realisation of speech, call and whistling, the four types of expression on the recording are not completely identical. As in other African tone languages, variations due to phonetical realisations, as [84] well as phrase intonation, are eliminated in the transposition of a spoken sentence on the slit-drum (Fürniss \& Guarisma 2005:468).

\subsection{The messages}

The messages of the three recordings can all be identified in Nekes' publications. Even the crossed out message "Looking for porters!" of cylinder $n^{\circ} 14$ is mentioned by Nekes (1912:78), but not transcribed or commented on.

\section{Archiv Jaunde $n^{\circ} 2$}

The documentation sheet gives only the meaning of cylinder $n^{\circ} 2$ in a close to litteral translation: "She gave birth to child male". This phrase can be found at the beginning of exercise 10b of Nekes' Manual (1911a:231):

\begin{tabular}{|l|l|}
\hline She gave birth to a little boy. & {$[1]$} \\
\hline If they hate you, they are up to something against you. & {$[2]$} \\
\hline Come to me tonight. & {$[3]$} \\
\hline If someone tells you that I am still on a walk, do not believe him. & {$[4]$} \\
\hline I have already come back from my walk. & {$[5]$} \\
\hline Why have you decided not to obey? & {$[6]$} \\
\hline
\end{tabular}

Nekes' German translation ${ }^{16}$ is preceded by a text which presents the six phrases in three realizations ${ }^{17}$ : "drum", "far-call", "spoken language" (Nekes 1911a:230-1; my translation):

[85]

\begin{tabular}{|c|c|}
\hline 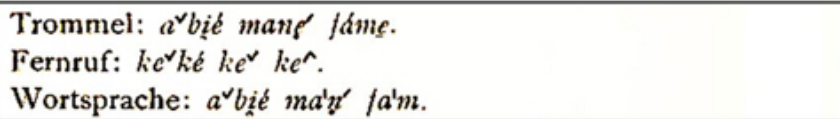 & [1] \\
\hline 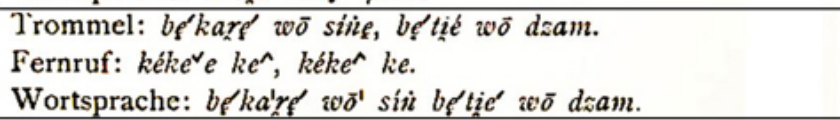 & [2] \\
\hline 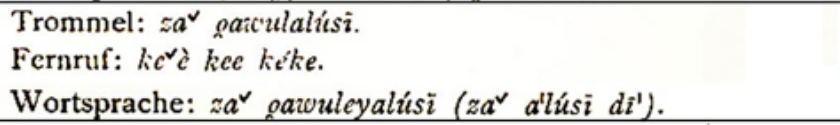 & [3] \\
\hline 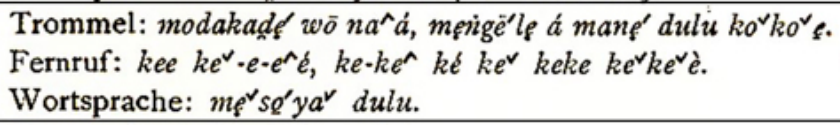 & {$[4+5]$} \\
\hline 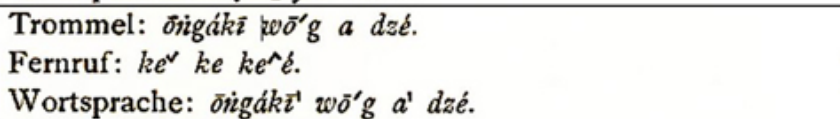 & [6] \\
\hline
\end{tabular}

\footnotetext{
16 "Sie hat ein Knäblein geboren. Wenn sie dich hassen, dann führen sie auch etwas gegen dich im Schilde. Komme heute nacht zu mir. Sollte dir jemand sagen, ich sei noch auf dem Spaziergang, so glaube es nicht. Ich bin schon vom Spaziergang zurückgekehrt. Warum hast du dir vorgenommen, nicht zu gehorchen?"
} 
The recorded message is truncated and reduced to its first sentence. Indeed, sentence [1] corresponds to what is said on cylinder $n^{\circ} 2$, although the last syllable is not pronounced. The sens is the same in both sources, but Nekes' written translation is more poetic in the Manual ${ }^{18}$.

[86]

\section{Archiv Jaunde $n^{\circ} 3$}

It seems that the continuation of Nekes' exercise 10 is recorded on cylinder $n^{\circ} 3$, although this relationship is not mentioned on the documentation sheet. Hornbostel writes:

\begin{tabular}{|l|l|l|l|}
\hline Basin wo a zïzï & They hate you without a reason & $\begin{array}{l}3 \text { times the "ndan", drum name } \\
\text { of the called person. }\end{array}$ & {$[2 ?]$} \\
\hline man kal Ambase Menie Tû & Child of Menie Tû's sister & Genealogy of the called person. & {$[\mathrm{X}]$} \\
\hline $\begin{array}{l}\text { Ongaki wog a dze } \\
\text { mod akade wo nâ mengel a } \\
\text { man dulu kokoe kokoe }\end{array}$ & $\begin{array}{l}\text { The man says to you that I am } \\
\text { still on a march, no, no }{ }^{19} .\end{array}$ & $\begin{array}{l}2 \text { or } 3 \text { times "ndan" of the } \\
\text { calling person. }\end{array}$ & {$[6]$} \\
\hline
\end{tabular}

The transcription of the spoken text which can actually be heard on the recording is quite close to Hornbostel's notation, as shows my phonetic transcription ${ }^{20}$ :

\begin{tabular}{|c|c|}
\hline [bâsí wò á zùzû] (3x) & [2?] \\
\hline [mán kál àmbásé Mèniè Tû] & {$[\mathrm{X}]$} \\
\hline [bâsí wò á zùzû] & [2] \\
\hline [ว́ndźk ò wóg â] (2x) & [6?] \\
\hline 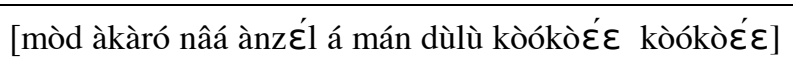 & {$[4+5]$} \\
\hline [ò wóg â] (2x) & {$[6 \mathrm{~b}]$} \\
\hline
\end{tabular}

The difference between what is written by Hornbostel and what may be heard on the recording indicates that Hornbostel has asked Joseph Ayisi what he has drummed and that he did not verify if the two expressions were really identical. This is a very common issue in a fieldwork situation: variation processes are extremely common and therefore two successive realizations of [87] the same piece are rarely identical. In my personal experience, the notation of song lyrics after a recording gives rarely the exact version of what has been sung. Hornbostel was visibly not aware of this phenomenon.

\footnotetext{
${ }^{17}$ The transcription method follows the convention used in Germany at the beginning of the 20th century (Nekes 1911a:213-4).

18 "Sie hat geboren Kind männlich" (Ms Phonogramm-Archiv); "Sie hat ein Knäblein geboren" (Nekes 1911a:231).

19 "Sie hassen dich ohne Grund. Kind der Schwester des Menie Tû. Warum willst du nicht gehorchen? Mensch er sagt dir so ich bin noch auf dem Marsche, nein, nein."

${ }^{20}$ I warmly thank Kisito Essele Essele for having reviewed my transcription.
} 
Yet also the written versions differ, as the contents of Hornbostel's recording is not identical to Nekes' version: sentence [2] is only recognizable through a segment of the German translation, as the Ewondo text is totally different; sentence [3] is absent and replaced by another sentence; sentences [4-5] and [6] are inverted. Though they have the same contents, they are not expressed in the same way.

Hornbostel indicates the structure of the message which is introduced by the identification of the recipient and the sender through their drum name ndán. In his article on drum-language, Nekes establishes an equivalence between the two utterances of sentence [2] corresponding to the name of the called person:

"Let us also mention the following called name: kékèéè kéè kékéè kè, in spoken language: békàré wò sinè, bétié wò dzàm, 'when they hate you, they are up to something against you', or shorter: kéè ké kèe kè kè, básín wò á zìzì 'they hate you without reason'" (Nekes 1912:82).

It seems that both versions are concatenations of phrases that can be used in different contexts. Nekes presents also another use of sentences [4+5]:

"There is someone who informs his friend that he is back from a journey. He lets speak the wooden mouth: 'Man, he tells you this, I were still on a journey, no, no' mot adzo oa na, mengel a dulu, kokoe kokoe (if someone tells you that I am not back from my journey yet, it is an error)" (1912:78).

It is interesting to see that - just as in any oral litterature - the three mentions of the same sentence are not identical, neither in the Ewondo example, nor in the translation ${ }^{21}$.

Sentence [6], identified by Hornbostel as being the drum name of the calling person, appears in Nekes' article as an example for the multiple layers of meaning of these names:

"The ndan describes a characteristic of the called person or his ancestor. Normally, at the same time as the child receives the short personal name of a parent, he also receives his drum call [...] The characteristic expressed by the drum name concerns only the first bearer of the name [...] The following [88] are some Ewondo drum names with their explanations:

\begin{tabular}{|c|c|c|c|c|c|c|}
\hline Drum beats ${ }^{22}$ & $l^{2}$ & $h^{l}$ & $l^{2}$ & $h^{l}$ & $l^{2}$ & $h^{l}$ \\
\hline Call (drum syllables) & $k \grave{e}$ & $e^{\prime}$ & $k \grave{e}$ & ké & $\grave{e}$ & $e ́$ \\
\hline $\begin{array}{r}\text { or: } \\
\end{array}$ & kù & ú & kù & $k u ́$ & $\begin{array}{l}\grave{u} \\
\grave{a}\end{array}$ & $\begin{array}{l}u \\
d z e ́\end{array}$ \\
\hline
\end{tabular}

Meaning: Strange, how you keep to your decision not to listen to the admonitions of the Elders.

Explanation: $k i$ to maintain oneself, to impose an interdiction upon oneself. wòk to feel, to hear, to obey. dzé? what? à dzé in expressions of astonishment, like in German: what a .

The first bearer of this drum name was an audacious warrior. When his brothers lay before an enemy village in the foggy night and still cogitated if they could dare to attack, he, without listening to the admonitions of the Elders, crept into the village of the enemies and nearly was caught as a slave. Angrily, they accused him of foolhardiness and pronounced these words which became later his name on the drum and since then has been transmitted to many of his descendants" (Nekes 1912:81).

\footnotetext{
21 "Mensch er sagt dir so ich bin noch auf dem Marsche, nein, nein" (Hornbostel, MS Phonogramm-Archiv). "Sollte dir jemand sagen, ich sei noch auf dem Spaziergang, so glaube es nicht. Ich bin schon vom Spaziergang zurückgekehrt" (Nekes 1911a:231). "'Mensch, er sagt dir so, ich bin (sei) noch auf Reisen, nein, nein' (sollte dir jemand sagen, ich sei noch nicht von der Reise zurückgekehrt, so ist das ein Irrtum)" (Nekes 1912:78). ${ }^{22} \mathrm{~h}=$ high tone; $1=$ low tone; the numbers indicate the two possible points where to beat the slit-drum (Nekes 1912:76).
} 


\section{Archiv Jaunde $n^{\circ} 13$}

Cylinder $n^{\circ} 13$ can also be identified thanks to Nekes' article. The documentation sheet contains only an explanation of the recorded message, somewhere situated between a translation and a commentary:

"He is on his way and calls his mother 'that his belly is like a small monkey that jumps from tree to tree' (he is hungry)".

This explanation is a very good example for the difficulty of establisehing a precise transmation when the researcher does not speak the recorded language and thus has to combine parts of the litteral translation an explanations which are generally mixed up in the informats discourse.

Luckily, the linguist fills the gap between the utterance, its large semantic field and its cultural context. According to Nekes (1912:74), this message is sent out by a hungry patriarch who calls back his wives from their work in the fields in order to prepare him a meal. It is an example [89] for the important semantic distance between a common expression and its poetic metaphor:

"In prose, 'I feel hungry' is said: mà-wó ziè. [The Ewondo-patriarch's] 'spoken' reflection contains only three syllables; but he actually drums the number, the tones and the rhythmic sequence of the syllables of the long figurative expression for hunger, i.e.:

àbùm á-nè mè àné màn ókókòe à-kàlàn mìntùt

Belly it is to me like little monkey (which) he climbs on trees.

The agile monkey (òkókòe, diminutive of kòe) sways from liana to liana, from branch to branch; doing so, its body extends and looses its rounding. In sign language, the Ewondo imitates the monkey by forcing the belly back into the abdominal cavity and showing a pitiable face: the gesture of hunger" (ibid.).

Nekes insists on the poetic dimension of the drum messages and states that many young people are not aware of the real meaning of a longer message, but only know its common synthetic meaning (ibid.).

\section{Song lyrics of Archiv Jaunde $n^{\circ} 1$ and 6}

The lyrics of two songs recorded by Hornbostel can also be found in Nekes' Manual (1911a). The "lullaby" on cylinder $\mathrm{n}^{\circ} 1$ is transcribed and translated p. 229, and p. 234-5 contain the Tale of the disobedient son in which appear the lyrics of the song of cylinder $n^{\circ} 6$. Hornbostel's documentation for this song mentions "See P. Necke's Jaunde Grammar" [sic].

The fact that one finds the same examples by both authors are strong indicators for a direct contact between them. Chronology provides a particular evidence, as the recordings from 1909 precede the public accessibility of the data published in Nekes' Manual of 1911 and in his article of 1912.

\subsection{The musicians, collaborators of both scholars}

Hornbostel's documentation sheets indicates the musician's name and provides some other data on the person. 
Joseph Ayisi

For Archiv Jaunde, one reads:

"Josef Ayisi, Ewondo (Jaunde)

Clan Edzo about 15-16 years, in Europe since july 1909. 3 years of missionary school in Yaounde, can read and write German and sing European songs. [90] [handwritten adding:] plays mouth organ with keys"

One can suppose that Ayisi was a competent message drummer, as Nekes stated that "there is hardly any adult who can't drum" (1912:78). Without the help of Ayisi, Nekes could not have written his Manual, as it is "the exact graphic reproduction of the words and the sentences as they have been pronounced by the indigeneous Joseph Ayisi" (Nekes 1911a:V).

Their collaboration started shortly after the opening of the Mvolyé missionary school in 1903, when Ayisi has been integrated as a teacher (Laburthe-Tolra 1999:184). He was still very young at this age - being born "about 1890", he was about 13-15 years old - but he already excelled by his intelligence and his qualites as an orator (Essono 2013:300). He became rapidly a collaborator for the translation of the first Ewondo catechism from 1910, which is signed by Nekes and Ayisi as co-authors according to Laburthe-Tolra (1999:186).

"The result was a chef-d'œuvre. According to several testimonies in a society in which the oratory art is of highest importance, many Beti went to the mess in order to hear these texts that they judged as being of an extraordinary formal beauty" (ibid.).

Ayisi had a crucial role in the Christian mission in Cameroon and his qualities are confirmed by Aloyse Essono in his book on the history of the catholic church in Cameroon:

"He is an excellent orator. His eloquence attracts crowds to Mvolyé. His astonishing sens of the language is recognized as being one of the major successes of the christianism among the Beti" (Essono 2013:300).

Ayisi came to Germany together with Nekes in order to assist him in the elaboration of the Manual (Nekes 1911c:22) and to follow a religious training in Einsiedeln (Essono ibid.). The sound recordings must have been made in the second semester of 1909, quite soon after Nekes' and Ayisi's arrival in Berlin on october $13^{23}$. Ayisi has stayed one year in Germany before going back to Cameroon (Nekes ibid.) where he worked as a catechist and teacher. The Journal of the Pallotine-missionaries published a photo that shows "Teacher Ayisi and Ota with their pupils" (Anonymous 1912:205). Another picture of these two men, taken in 1913, is published by Laburthe-Tolra (1999) and in Essono (2013). Together with his colleague Pius Otou, he ran the mission after the leave of the German Pallotine missionaries in 1916 (Essono 2013:301).

Hornbostel has been very well informed about the importance of qualifying a person by his clan-name. Thus, he identifies Ayisi as being of the Edzo-clan [91] which is also listed in Nekes' Manual (1911a:XIV). But he has probably not asked him for his year of birth, as he has a little bit underestimated his age. Joseph Ayisi died in Cameroon in 1947 (Essono 2013:300).

\footnotetext{
${ }^{23}$ GStA PK, I. HA Rep. 76 Kultusministerium, Va Sekt.2 Tit. X Nr 124 Adh V Bd. 6, leaflet 107 (october 21st, 1909). Hornbostel wrote "july 1909" as month of arrival, but I suppose that the official correspondance is more reliable.
} 


\section{Paul Mukeke}

Another Cameroonian musician recorded by Hornbostel collaborated also with Nekes. The recordings of Archiv Kamerun have been made in 1909 with Jakob Malapa from Kribi and Paul Mukeke from Malimba. The name of Mukeke is mentioned twice by Nekes (1928:82; 1911c:23), as he had worked with him in 1911 in Berlin in order to establish a comparative word-list for Ewondo, Basa, Duala and Bakoko terms. Nekes writes that Mukeke is Duala, whereas Hornbostel's list indicates that he was Bongo which is a clan-name of the Malimba. My Fieldwork conducted in 2015 confirmed that he was Malimba, but he spoke very well Duala and other languages from the Cameroonian coast. Little is known about him. It seems that he has not returned to Cameroon. At the actual state of knowledge, it is not possible to give more precisions. But even these few informations are sufficient to confirm that the network of scholars interested in Cameroonian cultures was composed by people who knew eachother.

\subsection{The recording site}

A handwritten addition to the second page of the Archiv Jaunde-documentation - listing the contents of cylinders $\mathrm{n}^{\circ} 4$ to 14 - indicates "in the Museum for Ethnography". In 1909, the Phonogramm-Archiv was still hosted by the Psychological Institute of the University (Ziegler 2005:197). Apparently, Hornbostel has recorded some cylinders of this collection in the Museum for Ethnography.

Although the typography of the documentation sheet seems to suggest that this concerned mainly the xylophone recordings ${ }^{24}$, it is not impossible that the drum language recordings have also been made in the Museum. Indeed, Nekes (1912:70) mentions a visit to the Museum together with Joseph Ayisi, where they checked all African slit-drums. Have the recordings been made at that occasion?

\subsection{Remaining doubts}

Having explored several paths that might reveal a direct contact between Hornbostel and Nekes, one has to admit that it is most probable that both [92] authors have met and that the recordings have been made on Nekes' initiative. However, a doubt remains as to an active research collaboration, as the documentation of the Phonogramm-Archiv contains no written evidence of a formal cooperation between these two scholars; and Nekes does not mention Hornbostel or his recordings at any place, neither in his book, nor in his article.

Also, the convergences do not necessarily imply Nekes' presence during the recordings. As Ayisi was Nekes' assistant for at least six years already, he knew perfectly the examples used by Nekes and the way of presenting the Ewondo's linguistic specificities. Ayisi could have been invited to the Archive at a different moment, as this was not uncommon for

\footnotetext{
${ }^{24}$ The recorded xylophone has the inventory-number III. C 1357. In 2012, this instrument was still in the catalogue of the Africa-Department of the Ethnological Museum in Berlin.
} 
foreigners living in Berlin (Ziegler 2005:199) and at that occasion have given the same examples to Hornbostel.

It is undeniable that there was a certain asymetric relationship between the two scholars, conditioned by the fact that Hornbostel needed Nekes' detailed ethnographic knowledge. The other way round, Nekes did not really need the phonograms for his research as he had gained enough insight in the use and the functioning of drum languages during the years he had spent in Cameroon.

There might finally have been only an indirect contact through the intermission of either Luschan, the Director of the Museum for Ethnography, or Carl Meinhof, Professor at the Oriental Seminar until Nekes arrived in Berlin. As Ziegler shapes out, Meinhof and his successor Diedrich Westermann were middlemen between the Archive and Africans living in Berlin. These linguists have been present at several recordings and were active in the preparation of the sessions (Ziegler 2005:200). The archives of the Museum for Ethnology contain a letter from Westermann to Hornbostel:

Berlin, december 6, 1911

Dear Dr [v. Hornbostel]!

Please allow me to submit to you a great request. Tomorrow evening, thursday, Father Nekes Cameroon gives a conference in the Colloquium of the Oriental Seminar about the musical tones in the languages of Cameroon, especially in Ewondo. It would be most precious for him and for us to present some phonographical recordings of the Ewondo language. Would you kindly put an apparatus and some cylinders at our disposal for this evening? [93] I would be very grateful. Mr Struck $^{25}$ has kindly promised to come to you in the Psychological Institute and to pick up the apparatus tomorrow at noon. - If ever you could manage to come yourself to the conference, this would be a great honour for us. Beginning at 6 o'clock.

Best greetings, respectfully yours

D. Westermann

It is not known if Hornbostel has been at this conference, nor if the material and the cylinders have really been lent ${ }^{26}$. The tone of the letter, however, shows clearly that he was not implicated in Nekes' research. Thus, it is quite possible that these recordings have been made as a kind of service in order to simply document by the sound what Nekes has published in a written form.

\section{Honour to Hornbostel's experimental protocol}

Although a genuine interdisciplinary research cannot be proven, it is necessary to pay tribute to Hornbostel's methodological perspicacity. His recordings represent a type of experimentation that provides evidence for the cognitive link between drum and speech patterns on the basis of relative pitch. As Christian Kaden (1986:38-39) has already pointed

\footnotetext{
${ }^{25}$ Probably the Bern[h]ard Struck who was present at this conference and illustrated on Nekes' personal Ewondo slit-drum some messages of "Bantu- and Sudan-negroes" that are not based on the imitation of spoken language (Nekes 1912:72). He is the author of several studies on Central African languages.

${ }^{26}$ In his notebook "Sendings, equipements, copies", Hornbostel mentions that Archiv Jaunde 2 has been played by himself at a conference on African music in the Seminar for Oriental Languages on april 25, 1913 and, together with Archiv Jaunde 13, in july 1914 (MS Phonogrammarchiv. File "Equipments", p. 42 et 44). But no hint as to Nekes' conference in 1911.
} 
out for other domains, Hornbostel has often identified problematics that were still relevant at the end of the 20th century. This is also the case in the domain of speech surrogates in which his experimental protocol is still a valid model for contemporary investigations on the subject, not only in a general cognitive perspective, but also in an ethnomusicological paradigm which takes into account the cultural uses and functions of this specific communication system.

\subsection{Experimentation based on ethnography}

By adding the "called" version in use among the Ewondo, Hornbostel anchored his experimentation in a solid ethnography, illustrating the specific Beti habit of transposing drum language back into a vocal expression. [94] The series of recordings - with the same experimental protocol ${ }^{27}$ - makes it possible to fully understand the linguistic principle that allows for the transposition of an utterance from natural language to a speech surrogate and back to a voiced utterance.

Although he never has done any field research, Hornbostel is also a predecessor for a methodological device that is still in use in African ethnomusicology. The whistled version of cylinder $n^{\circ} 2$ does not correspond to any cultural use and Nekes never mentions this means of isolation of the mere melodic parameter of a message. Thus, one may suppose that it was Hornbostel who asked the musician to do so. This builds a bridge to contemporary research, as this is still nowadays the method to verify, during field-work, the speech tones of terminologies and song-lyrics.

\subsection{Investigating the perception of language surrogates}

Another remarkable point from an ethnomusicological and linguistic perspective, is that the experimentation has taken into account both aspects of the communication, i.e. the production and the reception.

With cylinder $\mathrm{n}^{\circ} 13$, Hornbostel tries to investigate the efficiency of a long distance transmission by including in his experimentation the question of the perception of the message. He makes two recordings of the double-bell, one "close" and another one "far away". One may suppose that he has installed the phonograph in a gallery and that the bell was first played next to the apparatus and then at the farest possible point of the building. Unfortunately, this essential methodological aspect has not been developed or commented, neither by Hornbostel himself, nor by Nekes.

\section{An ideal representation of Hornbostel's work?}

As far as I know, nobody has made use of these recordings. In 1920, Hornbostel publishes an entry on "Drum language" in the German Colonial Dictionary. This text of high quality is a synthesis of the existing knowledge, but no indication is made concerning his own brief contact with this domain. He mentions the Ewondo, but explicites the relation between speech and drum tones by the example of the Duala, refering to the article of teacher Betz

\footnotetext{
${ }^{27}$ Except for Archiv Jaunde ${ }^{\circ} 5$.
} 
(1898). This seems to be a final evidence for the hypothesis that Hornbostel did not consider these recordings as beeing part of his own research. Therefore, my present "fieldwork in the archives" is the first attempt to give a real sens to these recordings and to save them from anonymity.

Knowing about the whole range of scientific questions risen by [95] Hornbostel's recordings, the 21 st century scholar that I am can only express her frustration that Hornbostel has not left more evidence for his reflections. And with his scientific background, wouldn't it be most astonishing if he had not built hypotheses about perception and cognitive processes of communication? My expectations are probably based on an ideal representation of Hornbostel's work. As Susanne Ziegler said (personal communication, march 6, 2012), the general perspective of the archive was primarily to "fill the gaps on the map of the world".

However, by placing his work at the intersection of ethnography, acoustics, and linguistics and by taking into account the reception of drummed messages, Hornbostel preceded most of the scholars who have investigated language surrogates even decades later. Only in 1976, the collaboration between Arom and Cloarec-Heiss explicites completely the cognitive premices of both aspects of the communicaton: encodation during the production and decodation during the reception. This crucial issue has already been foreshadowed in Hornbostel's recording protocol in 1909.

\section{[96]}

\section{References}

Abega, Séverin C., 1987, L'esana chez les Beti, Yaoundé, Editions Clé.

Abraham, Otto \& Erich M. von Hornbostel, 1904, Über die Bedeutung des Phonographen für die vergleichende Musikwissenschaft, Zeitschrift für Ethnologie 36, 222-236.

Ames, David W., Edgar A. Gregersen \& Thomas Neugebauer, 1971, Taaken Sāmāarii: A drum language of Hausa youth, Africa 41 (1), 12-31.

Anonymous, 1912, Rundschau aus den Missionsstationen, Der Stern von Afrika 7, 205-210.

Arom, Simha \& France Cloarec-Heiss, 1976, Le langage tambouriné des Banda-Linda (RCA), in L. Bouquiaux (éd.), Théories et méthodes en linguistique africaine, Paris, Selaf, 113-169.

Betz, R., 1898, Die Trommelsprache der Duala (Kamerun). Mitteilungen aus den deutschen Schutzgebieten, 1-86.

Bourget, Anne-Laure, 2013, La parole voilée, musiques de louange chez les Bwaba du Burkina Faso, PhD, Tours, Université François-Rabelais.

Cloarec-Heiss, France, 1997, "Langue naturelle, langage tambouriné : un encodage économique (banda-linda de Centrafrique)", in C. Fuchs et S. Robert (eds), Diversité des langues et représentations cognitives, Paris-Gap, OPRYS, 136-150.

Eboué, Félix, 1935, La clef musicale des langages tambourinés et sifflé (Essai linguistique musicale), Kongo-Overzee, Bulletin du Comité d'Etudes Historiques et Scientifiques de l'Afrique Occidentale Françaises 18, 235-360.

Essele Essele, Kisito, 2008, "Bia bi awu”. Mort et chants funéraires chez les Beti du SudCameroun, Master's Thesis, Strasbourg, Universite Marc-Bloch.

Essono, Aloyse Kisito Patrice, 2013, L'annonce de l'Évangile au Cameroun, Paris, Karthala.

Essono, Jean-Marie, 2000, L'Ewondo. Langue bantu du Cameroun. Phonologie, Morphologie, Syntaxe. Yaoundé, PUCAC/ACCT.

Fürniss, Susanne \& Gladys Guarisma, 2005, Des hauts et des bas : les tons dans les chantefables bafia, in E. Motte-Florac \& G. Guarisma (eds), Du terrain au cognitif. 
Linguistique, ethnolinguistique, ethnosciences. À Jacqueline M.C. Thomas, LouvainParis-Dudley (MA), Peeters, 431-475.

Grupe, Gerd, 1998, E. M. von Hornbostel und die Erforschung afrikanischer Musik aus der armchair-Perspektive, in S. Klotz (ed.), "Vom tönenden Wirbel menschlichen Tuns". Erich M. von Hornbostel als Gestaltpsychologe, Archivar und Musikwissenschaftler, Berlin, Schibri, 105-115.

Harttmann, Herrmann, 1933, Die Trommelsprache, Kamerun-Post 10 (2), 15-16. Heepe, Martin, 1919 (ed.), Jaunde-Texte von Karl Atangana und Paul Messi, nebst Experimentalphonetischer Untersuchungen über die Tonhöhen im Jaunde und einer Einführung in die Jaunde-Sprache, Hamburg, Friederichsen.

- 1919/20, Die Trommelsprache der Jaunde in Kamerun, Zeitschrift für Eingeborenensprachen 10, 43-60.

- 1919/20 (ed.) Weitere Jaundetexte von Paul Messi. Zeitschrift für Eingeborenensprachen $10,122-147$.

Heepe, Martin (unter Mitwirkung von P. H. Nekes), 1926, Jaunde-Wörterbuch, Hamburg, Friederichsen.

Hornbostel, Erich M. v., 1909, Wanyamwezi-Gesänge, Anthropos 4, 781-800, 1033-1052.

- 1913, Musik, in G. Tessmann, Die Pangwe, Berlin, Wasmut, Vol. 2, 320-327.

- 1917, Gesänge aus Ruanda, in J. Czekanowski, Forschungen im [97] Nil-Kongo-

Zwischengebiet, Saarbrücken, Fines Mundi, Vol. 1, 379-412.

- 1920, Trommelsprache, Deutsches Kolonial-Lexikon, Vol. 3, 536.

- 1928, African Negro Music, Africa 1 (1), 30-62.

- 1933, The ethnology of African sound-instruments. Comments on "Geist und Werden des Musikinstrumente" by C. Sachs, Africa 6, 129-157, 277-311.

Kaden, Christian, 1986, Vorwort, in C. Kaden \& E. Stockmann, Erich Moritz von Hornbostel. Tonart und Ethos. Aufsätze zur Musikethnologie und Musikpsychologie, Leipzig, Reclam, 21-39.

Laburthe-Tolra, Philippe, 1999, Vers la Lumière? ou le Désir d'Ariel. A propos des Beti du Cameroun. Sociologie de la conversion, Paris, Karthala.

- 1970, Yaoundé d'après Zenker (1895), extract of the Annales de la Faculté des Lettres et Sciences Humaines de Yaoundé 2.

Laburthe-Tolra, Philippe \& Jean-Marie Essono, 2005, L'ancien pays de Yaoundé, Paris, Maisonneuve \& Larose.

Lacombe, Claire, 2013, Pour une valorisation des archives de xylophones fang de 1907 à nos jours, Master's Thesis, Nanterre, Univ. Paris Ouest.

Luschan, Felix v., 1908 (3rd ed.), Anleitung für ethnographische Beobachtungen und Sammlungen in Afrika und Oceanien, Berlin, Königliches Museum für Völkerkunde.

Maho, Jouni F., 2009, NUGL Online. The online version of the New Updated Guthrie List, a referential classification of the Bantu languages, version dated 2 june 2009.

Meinhof, Carl, 1894, Die Geheimsprachen Afrikas, Globus 66, 117-119.

Nagel, Moritz, 2014, The Duala Drum Language: What Do We Know from Early Germanophone Sources?, in N. Riva, Klangbotschaften aus der Vergangenheit. Forschungen zu Aufnahmen aus dem Berliner Lautarchiv, Aachen, Shaker Verlag, 119156.

Ne Nkamu, Luyindula, 2011, Mvovo mia ngoma ou Les Paroles du tambour ngoma chez les Manianga du Kongo, cas du Ngoma'a Ntunta, Master's Thesis, Nanterre, Univ. Paris Ouest.

Nekes, Hermann, 1911a, Lehrbuch der Jaunde-Sprache, Berlin, G. Reimer.

- 1911b, Die Bedeutung des musikalischen Tones in den Bantusprachen, Anthropos 6, 546574.

- 1911c, Ein Wiedersehen, Der Stern von Afrika 1911 (1), 22-28.

- 1912, Trommelsprache und Fernruf bei den Jaunde und Duala in Südkamerun, Mitteilungen des Seminars für Orientalische Sprachen 15 (3), 69-83.

- 1928, Zur Tonologie der Bantusprachen, in W. Koppers (ed.), Festschrift P. W. Schmidt, Wien, Mechitharisten-Congregations-Buchdruckerei, 80-92.

Nketia Kwabena, Joseph H., 1963, Drumming in Akan Communities of Ghana, London, Nelson. 
Schmidt, Wilhelm, 1912, Einiges über afrikanische Tonsprachen. Im Anschluß an P. H. Nekes, P. S. M., Lehrbuch der Jaundesprache, Anthropos 7, 783-791.

Sebeok, Thomas A. \& Donna J. Umiker-Sebeok (eds), 1976, Speech Surrogates: Drums and Whistle [98] Systems, La Hague/Paris, Mouton.

Skolaster, Hermann, 1910, Die Trommelsprache und der Fernruf, in Kulturbilder aus Kamerun, Limburg, VKP, 106-108.

Tessmann, Günther, 1913, Die Pangwe, Berlin, Wasmut.

Thilenius, Georg, Carl Meinhof \& Wilhelm Heinitz, 1916, Die Trommelsprache in Afrika und in der Südsee, Vox 4/5, 179-208.

Tronje von Hagen, Gunther, 1914, Lehrbuch der Bulu-Sprache, Hamburg, Radetzki.

Worms, Ernest A., 1953, H. Nekes' and E. A. Worms' Australian Languages, Anthropos 48, 956-970.

Zemp, Hugo, 2004, Paroles de balafon, L'homme, 171-172, 213-233.

Zenker, Georg, 1895, Yaunde, Mittheilungen von Forschungsreisenden und Gelehrten aus den Deutschen Schutzgebieten 8, 35-70.

Ziegler, Susanne, 1998, Erich M. von Hornbostel und das Berliner Phonogramm-Archiv, in S. Klotz (ed.), "Vom tönenden Wirbel menschlichen Tuns". Erich M. von Hornbostel als Gestaltpsychologe, Archivar und Musikwissenschaftler, Berlin, Schibri, 146-168.

- 2005, "'Musikproben von allen Völkern der Erde'. Das Berliner Phonogramm-Archiv", in U. van der Heyden \& J. Zeller (eds), "...Macht und Anteil an der Weltherrschaft". Berlin und der deutsche Kolonialismus, Berlin, Unrast, 197-201.

- 2006, Die Wachszylinder des Berliner Phonogramm-Archivs, Berlin, Ethnologisches Museum, Staatliche Museen zu Berlin, Stiftung Preußischer Kulturbesitz.

\section{Appendix}

\section{Archiv Jaunde (Ziegler 2006, CD-Rom, Translation by S. Fürniss)}

Typewritten:

Jaunde-Phonogrammes, recorded in the Berlin Phonogramm-Archiv.

Josef Ayisi, Ewondo (Jaunde)

Clan Edzo about. 15-16, in Europe since july 1909. 3 years of missionary school in Jaunde, can read and write German, and sing European songs. [handwritten addition: plays Harmonica with keys]
1) Lullaby
a) two sung stanzas.
b) spoken.
c) last stanza sung.

2) Drum language.

"She gave birth to a child male"
a) drummed (several times)
b) spoken.
c) called (sung)
d) whistled.

[99] Text:

3) Drum language. Basin wo a zïzï

Basin wo a zïï They hate you without a reason man kal Ambase Menie Tû Child of Menie Tû's sister

Ongaki wog a dze

Why don't you want to obey? 3 times the "ndan", drum name of the called person. Genealogy of the called person. 2 or 3 times "ndan" of the mod akade wo nâ mengel a man dulu kokoe kokoe The man says to you that I am still on my way,

4) Dance rhythms on the wooden drum a)

b) idem no, no.

silences are beaten (with the left hand) on the not sounding 
5) Lament on the speechdrum.

6)

a) "Tale of the disobedient son"

b) Song from the tale "the talking bird" 2 stanzas

c) "Drinksong"

7) a) "Drinksong" (or Dancesong)

8) - 12) Xylophonerecordings

[100]

13) Double-bell

14) Drumlanguage.
"One has fled from soldiers, here I run in the forest, what have I done to the soldier.

I stand in the rain, etc."

b) Spoken text of 6)b)

c) Spoken text of 6)a)

recorded in the Museum for Ethnography

"He is on his way and calls his mother "that his belly is like a small monkey that jumps from tree to tree" (he is hungry)
a) Double-bell nearby.
b) Double-bell nearby
c) The same, far away
d) Called message
e) Spoken text.

The white man calls for porters ("Looking for porters") board

see P. Neckes Jaunde Grammar. (Song integrated in the tale. Refrain: Niki) Refrain: wan kën

(Many unsignificant syllables, esp. refrain, therefore more tones than in other songs.) (supposed to be Tessmann 16?)

(Words mainly improv.)

not complete

2 Repetition of 8

9. Repetition of 8

Complement to the Ewondorecordings: Scale of the used xylophone

halange III. C 1357.

a) unused tones

b) used tones

c) 2 more tones that may also have been used. 